\title{
Pigmented Bowen's disease (Bowenoid Papulosis) dermoscopically mimicking melanoma
}

\begin{abstract}
Pigmented Bowen's disease (PBD) is a rare variant of Bowen's disease. It is important to distinguish PBD from other pigmented skin lesions such as solar lentigo, pigmented actinic keratosis, keratoacanthoma, seborrheic keratosis, pigmented basal cell carcinoma, Spitz/Reed nevus, blue nevus, melanocytic nevi and melanoma. Dermoscopy is a useful, non-invasive method commonly used in the differential diagnosis of pigmented lesions. Here, we report a 51-year-old man with PBD, which was dermoscopically mimicking melanoma and was associated with human papilloma virus infection.
\end{abstract}

Keywords: Pigmented Bowen's disease, dermoscopy, melanoma

Öz

Pigmente Bowen Hastalığı (PBH), Bowen hastalığının nadir görülen bir varyantıdır. Solar lentigo, pigmente aktinik keratoz, keratoakantoma, seboreik keratozis, pigmente bazal hücreli karsinoma, Spitz/Reed nevüs, blue nevüs, melanositik nevüs ve melanoma gibi diğer pigmente deri lezyonlarından ayırt etmek önem taşımaktadır. Dermoskopi, pigmente lezyonların ayıııc tanısında sıklıkla kullanılan, faydalı, invaziv olmayan bir tanı yöntemidir. Burada, 51 yaşında dermoskopik olarak melanomu taklit eden, Human Papilloma Virüs enfeksiyonu ile ilişkili bir PBH olgusu sunulmaktadir.

Anahtar Kelimeler: Pigmente Bowen hastalığı, dermoskopi, melanom

\section{Introduction}

Pigmented Bowen's disease (PBD) is a rare clinical type of Bowen's disease (BD) and accounts for less than $2 \%$ of all cases $^{1-3} . \mathrm{BD}$ and bowenoid papulosis are considered the same entity ${ }^{4}$. It is important to distinguish PBD from other pigmented skin lesions such as solar lentigo, pigmented actinic keratosis, keratoacanthoma, pigmented eccrine poroma, angioma, angiokeratoma, seborrheic keratosis, benign lichenoid keratosis, pigmented basal cell carcinoma, Spitz/Reed nevus, blue nevus, melanocytic nevi, and melanoma ${ }^{1-3}$. Dermoscopy is a useful non-invasive method for differential diagnosis of pigmented lesions. Herein we report a 51-year-old man with PBD which is dermoscopically mimicking melanoma.

\section{Case Report}

A 51-year-old man with Fitzpatrick skin type 4 admitted to our dermatology out-patient clinic with a 9 years history of widespread verrucous papules on the pubis and penis. Dermatological examination revealed in addition

Address for Correspondence/Yazışma Adresi: Güldehan Atış MD, ìstanbul Haydarpaşa Numune Training and Research Hospital, Clinic of Dermatology, İstanbul, Turkey Phone: +90 5327927093 E-mail: guldehan.atis@gmail.com Received/Geliş Tarihi: 08.12.2017 Accepted/Kabul Tarihi: 19.07.2018 ORCID ID: orcid.org/0000-0001-5069-044X 
to verrucous papules, a $1.5 \times 1 \mathrm{~cm}$ sized, asymptomatic dark-brown plaque with irregular borders on the pubic region. Dermoscopic examination revealed the presence of irregular brown dots, a structureless hypopigmented area in the lower part, irregular radial streaks, abruptly terminated pigment network in the periphery, and multicomponent pattern and asymmetry (Figure 1). ELISA for Anti Human Immunodeficiency Virus was negative. The lesion was excised As a differential diagnosis melanoma and dysplastic nevus had been considered. Histopathological examination revealed parakeratosis, irregular acanthosis, cellular nucleomegaly, cytological atypia with increased mitotic activity, melanin pigment increase in keratinocyte and loss of polarity at all layers of epidermis (Figure 2,3). Using polymerase chain reaction analysis, human papilloma virus (HPV) 16, 18 and 45 were found to be negative whereas other high risk HPV $(31,33,35,39,51,56,58,59,66,68)$ were positive on the lesional biopsy sample. The patient was diagnosed as PBD accompanied by severe dysplasia with clinical and histopathological features. There was no lesion at the surgical margin. Written consent form was taken from the patient.

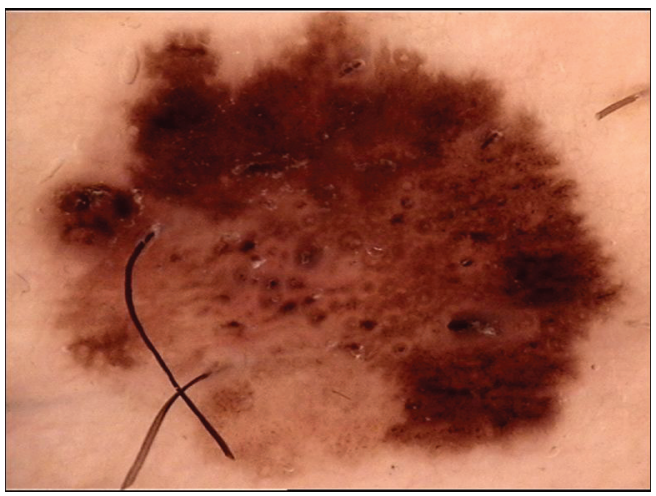

Figure 1. Presence of irregular brown dots, a structureless hypopigmented area in the lower pole, irregular radial streaks, abruptly terminated pigment network in the periphery, and multicomponent pattern and asymmetry

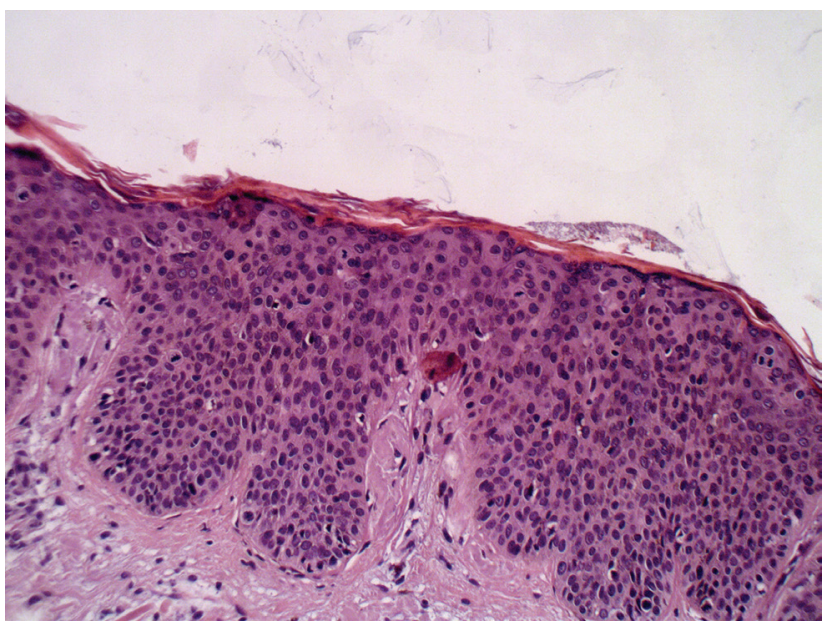

Figure 2. Parakeratosis, irregular acanthosis, cellular nucleomegaly, cytological atypia with increased mitotic activity, melanin pigment increase in keratinocytes and loss of polarity at all layers of epidermis

\section{Discussion}

$\mathrm{BD}$ is a form of squamous cell carcinoma in situ with a low potential of invasion. Sun exposure, gravity, arsenic ingestion, chronic trauma, immunosuppression, irradiation and HPV infection are etiological factors for developing BD. HPV infection is especially an important risk factor for genital BD as well as other non-sun-exposed areas a $^{3,5}$. It has been shown that, HPV subtypes 2,16,27,33,34,56,58,59,76 were related with $\mathrm{BD}$. HPV infection leads to down regulation of E6 and E7 proteins in the host chromosomes. This issue is responsible for malignant transformation ${ }^{5}$. In our case, high risk HPV subtypes were positive as triggering factor.

PBD is more common in patients with darker skin type. The skin type of our patient was Fitzpatrick $4^{3}$. Presence of melanin pigment in the cytoplasm of atypical keratinocytes and hyperfunction of melanocytes lead to pigmented appearance of BD. The mechanism of pigmentation in the PBD is still unclear. It is possible that neoplastic cells induce the melanocyte proliferation and melanin production of melanocytes by cytokines. Increased melanin pigment transfers to the cytoplasm of keratinocytes by dendritic branching ${ }^{1}$. One of the other hypothesis is that elevated temperature of the affected area can lead to hyperpigmentation and the other is that PBD may originate from a pigmented lesion ${ }^{3}$. In our case, increased melanin pigment was observed in keratinocyte in epidermis.

Argenziano et al. ${ }^{6}$ reported the presence of glomerular or coiled vessels as the first dermoscopic description of BD. Zalaudek et al. ${ }^{7}$ described the dermoscopic findings of a BD as blue homogeneous pigmentation, irregularly distributed blue gray granular structures, pigmented crust and white amorphous areas. Bugatti et al. ${ }^{8}$ described the dermoscopic features of BD. Multicomponent pattern, pseudo network, irregular streaks, blotches, regression, blue-whitish veil, hypopigmentation, and various vascular patterns such as dotted, bushy, hairpin, linear, arborizing are diagnostic criteria for BD. In 2010, Cameron et al. ${ }^{9}$ reported the largest series of PBD included 52 cases manifesting asymmetry (88\%), amorphous hyperpigmentation pattern alone or in combination with dots, amorphous hypopigmented areas (67\%), gray or brown dots in a linear arrangement (21\%) and the presence of coiled or dotted vessels in linear arrangement, as well as a pigment network

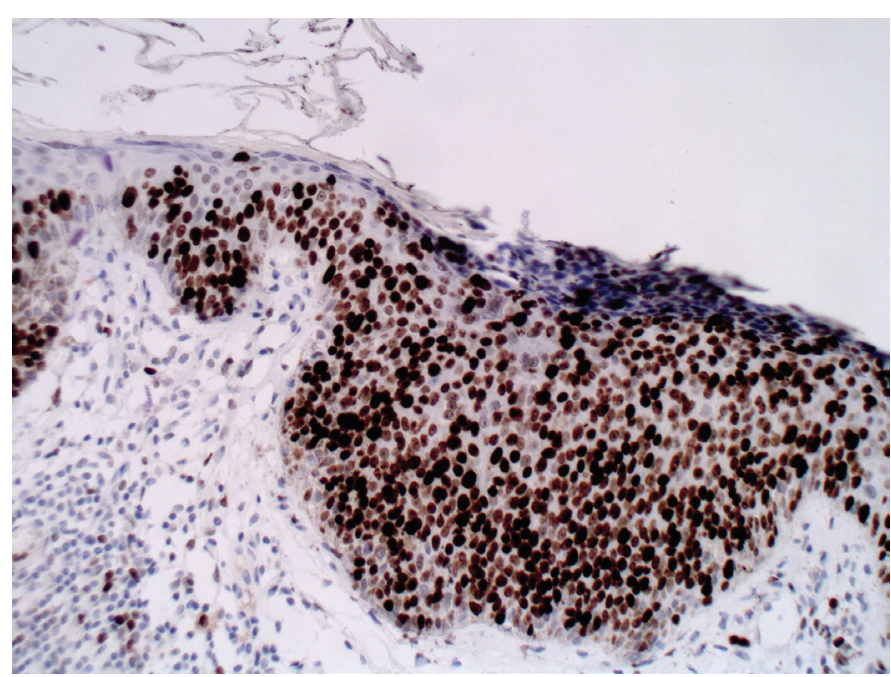

Figure 3. Positive-staining with $\mathrm{Ki}-67$ in full layer of epidermis 
(4\%). Maione et al. ${ }^{2}$ reported a PBD which presented with starburst pattern. In our case, we neither detected polymorphic vascular pattern nor starburst pattern but only we detected irregular brown dots, a structureless hypopigmented area, irregular radial streaks, abruptly terminated pigment network in the periphery, multicomponent pattern and asymmetry.

\section{Conclusion}

PBD is a rare entity which is important to differentiate from other pigmented skin lesion. HPV infection can be etiological factor especially for the lesions on the genital area. Dermoscopy is an important and non-invasive method for recognizing pigmented and non-pigmented skin lesions. It is so important to define the dermoscopic features of PBD. Sometimes histopathological examination may be necessary to diagnose the lesion accurately and differentiate it from other pigmented lesions.

\section{Ethics}

Informed Consent: Written consent form was taken from the patient. Peer-review: External and internal peer-reviewed.

\section{Authorship Contributions}

Surgical and Medical Practices: G.A., Concept: G.A., Ş.Y., Design: G.A., F.G., Data Collection or Processing: G.A., Ş.Y., S.A., P.G., Analysis or Interpretation: G.A., Ş.Y., Literature Search: G.A., Ş.Y., P.G., Writing: G.A.
Conflict of Interest: No conflict of interest was declared by the authors.

Financial Disclosure: The authors declared that this study received no financial support.

\section{References}

1. Ishioka P, Yamada S, Michalany NS, Hirata SH. Dermoscopy of Bowen's disease: Pigmented variant on the penis. An Bras Dermatol 2012;87:482-4.

2. Maione V, Errichetti E, Rousel SL, Lebbe C. Pigmented Bowen's disease presenting with a "starburst" pattern. Dermatol Pract Concept 2016;6:47-9.

3. Öztürk Durmaz E, Doğan Ekici I, Özkan F, Şahin S. Pigmented Bowen's disease of the genitalia masquerading as malignant melanoma. Acta Dermatovenerol Croat 2015;23:130-3.

4. Bolognia JL, Jorizzo JL, Rapini RP. Dermatology. 2nd edition. St. Louis: Mosby Elsevier, 2008;1171-86.

5. Gahalut P, Rastogi MK, Mishra N, Chauhan S. Multiple pigmented Bowen's disease: A diagnostic and therapeutic dilemma. Case Rep Oncol Med 2012;2012:342030

6. Argenziano G, Zalaudek I, Corona R, et al. Vascular structures in skin tumors, a dermoscopy study. Arch Dermatol 2004;140:1485-9.

7. Zalaudek I, Argenziano G, Leinweber B, et al. Dermoscopy of Bowen's disease. Br J Dermatol 2004;150:1112-6.

8. Bugatti L, Filosa G, Angelis R. Dermoscopic observation of Bowen's disease. J Eur Acad Dermatol Venereol 2004;18:572-4.

9. Cameron A, Rosendahl C, Tschandl P, Riedl E, Kittler H. Dermatoscopy of pigmented Bowen's disease. J Am Acad Dermatol 2010;62:597-604. 